\title{
VARIATION OF ERGATIVITY PATTERNS IN INDO-ARYAN ${ }^{1}$
}

\author{
KRZYSZTOF STROŃSKI \\ Adam Mickiewicz University, Poznań \\ stroniu@amu.edu.pl
}

\begin{abstract}
Ergativity in the Indo-Aryan languages is a very intricate phenomenon. At the morphological level, we can observe a certain continuum, from disappearance of ergativity to its reinforcement. The first tendency is clearly visible not only in Eastern Hindi and Bihari dialects, but also in Western Rajasthani. The second tendency can be noted in the Pahari dialects. Somewhere in between are the Western Hindi dialects, which have introduced analytical marking for agent and patient. The transitional character of ergativity in Indo-Aryan can be observed in considering the alignment of the three syntactic-semantic Dixonian primitives, namely A, S, and O (Dixon 1979; 1994). It appears that, in fact, all possible alignments are traceable, even that in which A and O receive the same marking and which has been excluded by typologists (Comrie 1978). However, extending the Dixonian three-primitive system by Obl. (Klimov 1983), we can also observe that the same treatment of A and Obl. (perceived as one of the implications of ergativity) is shared by, for example, early Rajasthani, contemporary Pahari and Western Hindi, where it is closely connected with the polyfunctionality of the ergative postposition.
\end{abstract}

KEYWORDS: Ergativity; Indo-Aryan; morphosyntactic alignment.

\section{Introduction}

It has been already demonstrated in the literature that the majority of ergative IndoAryan languages show a constant drift towards nominativity (e.g. Pirejko 1968). An interesting fact is that destructuring of the split ergative system has resulted in the emergence of various syntactic patterns which do not fit generally accepted typological characteristics. It seems that a detailed study of agreement and case marking in Hindi and the dialects spoken the area usually associated with the so-called "Hindi belt" shows the existence of all kinds of morphosyntactic alignments and makes it possible to demon-

\footnotetext{
${ }^{1}$ This paper is a part of a research project supported by Ministry of Science and Higher Education grant $\mathrm{N}$ N104 215833.
} 
strate the ergativity continuum in the core of IA languages. Here the preliminary results of such research will be concisely presented.

The data examined by the present author come from vernacular grammars, texts and two field trips to India in 2008. Where necessary, historical sources have also been explored in order to demonstrate the general tendencies observable in the split ergative system represented by selected IA dialects.

\section{Traditional views}

The standard view on ergative vs. accusative alignment has been summarized in the works of Dixon (1979; 1994; see Figure 1) although it should be noted that his proposal was in many respects identical with that presented in the works of Meščaninov (e.g. 1967: 22, 167) or Klimov (1973: 87). It is disputable whether the so-called semanticsyntactic primitives (Dixon 1994: 6), i.e. A (transitive subject), S (intransitive subject) and $\mathrm{O}$ (transitive object), are capable of modeling the basic alignment types occurring in the languages of the world, and therefore in the present paper I will refer to the more semantic interpretation of those symbols. Thus, A will stand for the agent-like argument of a transitive verb, $\mathrm{O}$ - the patient-like argument of a transitive verb, and $\mathrm{S}$ - the single actant of an intransitive verb. This is partly along the lines of the proposal offered by Manning (1994: 3; 19-20), according to whom the syntactic status of the main arguments is of secondary character.

Having employed the notational convention of Dixon, I have stuck to semantic notions which are of universal character and which are sufficient for the purpose of my presentation. Consequently, the problem of subject and object will not be dealt with here, since these categories cannot be considered an organizational basis for languages.

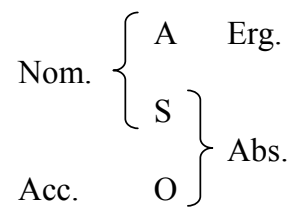

Figure 1. Nominative-accusative vs. ergative-absolutive alignment (Dixon 1979, 1994).

Before Dixon's seminal paper was published (1979), the phenomenon of ergativity had been discussed from the typological perspective, and several views expressed in the 1970s regarding morphology and agreement in the ergative construction gained great popularity, often still being quoted today. Some of them have even become so pervasive that the existing language data has been either neglected or purposely overlooked. Let 
us cite below only three of them which are considered relevant to the topic of the present paper:

- "there are apparently no languages in which an ergative verb-agreement rule is combined with a nominative-accusative case marking system" (Anderson 1977: 329-330);

- "In fact, there are many languages which have an ergative-absolute system for nominal case-marking and a nominative-accusative system for verb-agreement (the inverse is rare or nonexistent)." (Comrie 1978: 340);

- "no language combines a tense/aspect split with the absence of case marking" (Trask 1979: 389).

To those mentioned above, one can also add that, according to typologists, the ergative Indo-Aryan languages, being of the tense/aspect split type, should not show object-verb agreement in person (only in gender), and NP split based on the Silverstein hierarchy (Trask 1979: 389). The claim that the grouping together of A, O with S marked differently $(\mathrm{A}=\mathrm{O}, \mathrm{S})$ is nonexistent (Comrie 1978: 330) can also be adduced.

In the following section, I will try to demonstrate how some ergativity patterns attested in the IA dialects directly violate the aforementioned universals.

\section{Counterevidence from selected IA dialects}

Contrary to the first two claims, co-existence of ergative verbal agreement and nominative case marking has been attested in Rajasthani dialects, e.g. in Marwari and Shekhavati. In the example (1) $\mathrm{A}$ is unmarked and $\mathrm{O}$ receives postpositional marking (i.e. nominative case marking) but verbal agreement is with $\mathrm{O}$ and not with A (i.e. ergative agreement). The falsification of the third claim comes from the evidence for aspect split without case marking which is found in Rajasthani dialects e.g. Marwari, Shekhawati. In such cases the only indicator of ergativity is OV agreement (cf.(2) and (3)).

$$
\text { ram sita-ne } \quad \operatorname{dek}^{\mathrm{h}} \mathrm{i}
$$

ram.Nom. Sita.fem.Acc./Dat. see.PPP.fem.sg.

'Ram saw Sita.' (Marwari)

$$
\text { th }{ }^{\text {h }} \text { oro kela mol leve he }
$$

boy.Dir.masc.sg. banana.masc.pl. price take.PImp. be.3sg.pres.

'A boy buys bananas.' (Shekhawati) 
(3)

$$
\begin{aligned}
& \mathrm{t} \int^{\mathrm{h}} \text { oro } \quad \text { kela } \quad \text { mol } \quad \text { lija } \\
& \text { boy.Dir. } \quad \text { banana.masc.pl. } \text { price } \quad \text { take.PPP.masc.pl. } \\
& \text { 'A boy bought bananas.' (Shekhawati) }
\end{aligned}
$$

The "impossible" OV person agreement is attested, for example, in Pahari (4), in the perfective domain in constructions with unmarked pronominal $O$. The passive value of the construction showing this type of agreement has been mentioned by some scholars (cf. Sharma 1987: 97; 1994: 206-207), but its passivity is purely formal. In some Kumauni dialects (e.g. Gangoli), it is still the basic active construction in the perfective tenses, although it has to be emphasized that object marking has almost ousted the unmarked pronominal forms in the ergative domain in Kumauni (and generally in Eastern Pahari ${ }^{2}$ ), and the syntactic type represented by example (4) may soon become obsolete, being ousted by the pattern with default agreement (5), which is equivalent to MSH.

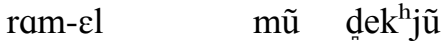

$$
\begin{aligned}
& \text { Ram.Post.Erg. I see.PPP.1sg. } \\
& \text { 'Ram saw me.' (Gangoli) }
\end{aligned}
$$

$$
\begin{aligned}
& \text { ram- } \varepsilon 1 \quad m i-k \varepsilon \quad \operatorname{dek}^{\mathrm{h}} \mathrm{O} \\
& \text { Ram.Post.Erg. I-Post.Dat./Acc. see.PPP.masc.sg. } \\
& \text { 'Ram saw me.' (Kumauni) }
\end{aligned}
$$

Although it appeared to linguists that a tense/aspect split excludes the NP split based on the Silverstein hierarchy, the latter can be found e.g. in Rajasthani - in all Western dialects 1st pers. A remains unmarked, in Bagri A below 2nd pers. takes Erg. (6) and in Marwari and Shekhavati (inconsistently) A below 3rd pers. takes Erg. (cf. (7) and (8)). A similar phenomenon is apparently existent in Panjabi, where the 1st pers. pronoun is the only one which is unmarked in the perfective tenses.
t $\tilde{\varepsilon}$
á kItrab
koni pədi
he
you.Erg. this book.fem.sg neg. read.PPP.fem.sg. be.aux.2sg.
'You haven't read this book.' (Bagri) (Gusain 2000: 62)

\footnotetext{
${ }^{2}$ I do not pick up the thread of the discussion on the Grierson classification of the Pahari tongues, but I do favor the hypothesis formulated by Joshi and Negi (1994) and Joshi (2009) stating that the notion of "Central Pahari" is unjustified in the light of the available epigraphic data. According to him Nepali, Kumauni and Garhwali should be classified under the rubric "Eastern Pahari". Following the main lines of this theory, I will consequently use the term "Eastern Pahari" while referring to Garhwali and Kumauni together.
} 
(7)

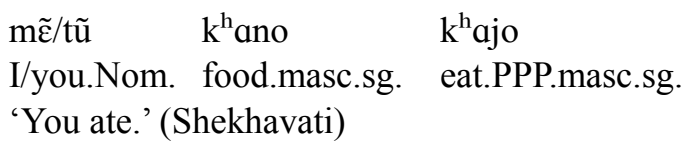

(8)
(a)bəy
(b) bo/ba
$\overline{\mathrm{t} \int a j}$
pi
s/he.Erg. he/she.Nom tea.fem.sg. drink.PPP.fem.sg.
'S/he drank tea.' (Shekhavati)

It is thus obvious that such modest language data excerpted randomly from a few NIA dialects proves the inadequacy of the general statements regarding ergative alignment presented above.

In the next sections, we will briefly explore the phenomenon of agreement and the problem of $\mathrm{A}$ and $\mathrm{O}$ marking, which in turn should enable us to construct an adequate ergativity scale.

\section{Agreement}

The most recent and extensive survey on agreement in Hindi and other IA languages (Das 2006) has demonstrated the existence of two major types of agreement, i.e. single and double agreement.

- The single agreement pattern is represented exclusively by accusative languages. The verb always agrees with A.

- Double agreement is attested in split ergative languages. The verb can agree with A or O.

Hindi/Urdu is a classical example of the double agreement system. In the imperfective tenses, the verb agrees with A(9), and in the perfective tenses - either with $\mathrm{O}(10)$ or, if $\mathrm{O}$ is marked, then the agreement is blocked and the verb takes a default form (11). ${ }^{3}$

$$
\begin{aligned}
& \text { ram film dekh roha } \quad \text { he } \\
& \text { Ram film see cont. masc. } \\
& \text { 'Ram is seeing a film.' (MSH) }
\end{aligned}
$$

\footnotetext{
${ }^{3}$ The transitive verb used in the perfective aspect does not always trigger A marking and OV agreement as it can be the case for complex predicates (cf. Butt 1995: 90; Das 2006: 134-135). If the light verb conjoined with the transitive verb is intransitive, we actually have an "intransitivized" transitive construction which formally resembles the antipassive.
} 


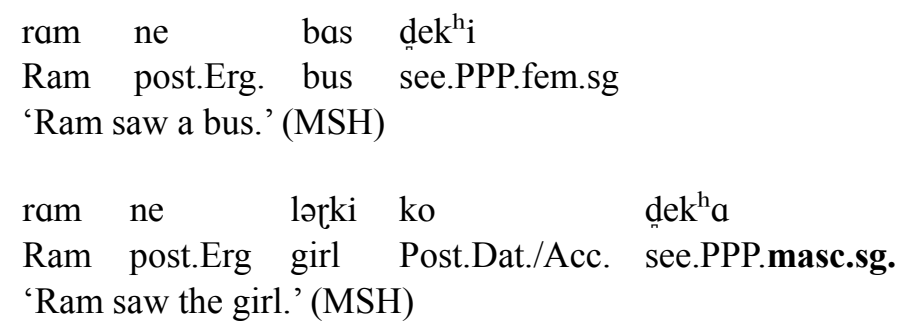

Notwithstanding, certain IA languages do not follow the rule of agreement blocking and, despite introducing $\mathrm{O}$ marking, they still preserve $\mathrm{OV}$ agreement. The widely discussed example is Marwari (conforming to the neighboring Gujarati pattern; cf. Magier 1983: 321), but the absence of agreement blocking has also been attested at earlier stages of Pahari (Grierson 2005: 294-295; 398-399) and Braj (Liperovskij 1988, 2007).

It has always been tacitly assumed that the pronominal system of NIA follows default agreement in the perfective tenses. However, the introduction of the pronominal $\mathrm{O}$ marking seems to be a recent phenomenon, and still some dialects show the unmarked pronominal O (Eastern and Western Pahari) in the perfective tenses.

Scrutiny of the pronominal system and the status of the main and auxiliary verb in the ergative domain reveals further intricacies of the agreement patterns existing in the IA dialects:

- The phenomenon of the split agreement attested in Rajasthani (Magier 1983:321322; Khokhlova 2001: 168) and Awadhi (Liperovskij 1997: 241).

- Complex agreement in Pahari and Braj with the 1st and 2nd pers. pronominal O.

- Agreement of pronominal $\mathrm{O}$ with the main verb in Rajasthani, Pahari and Western Hindi.

\subsection{Split agreement}

This type of agreement is rare; it has been reported for Marwari, but spoken away from its center, i.e. Jodhpur (Bahl 1972: 15). It actually combines two types of verbal agreement, namely ergative - the participial form agrees with $\mathrm{O}$ in gender - and nominative - the auxiliary agrees with A (if the object is marked, still the agreement blocking rule is non-operational; cf. (12) and (13)). Split agreement is a result of two tendencies towards nominativization, namely cross-referencing of person on the auxiliary and introduction of the $\mathrm{O}$ marker - both being considerably new developments.

$$
\begin{aligned}
& \text { mhẽ } \quad \varepsilon r i \quad \text { dukanã } \quad \operatorname{dek}^{\mathrm{h}} \mathrm{i} \quad \text { hũ } \\
& \text { I such shop.fem.pl. see.PPP.fem. be.aux.1st.sg. } \\
& \text { 'I have seen also this kind of shops.' (Marwari) ("Mānak" 2008, Jan. 44) }
\end{aligned}
$$




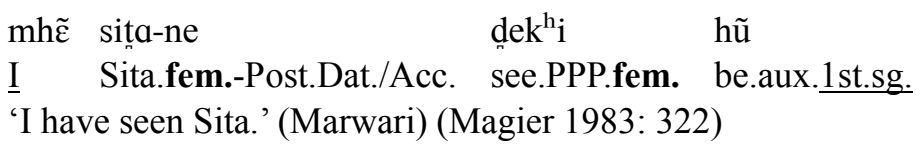

The Marwari examples constitute a proof of the co-existence of nominative case marking and ergative verb agreement, and the tendency towards nominativity seems to be further strengthened by the two types of verbal agreement.

\subsection{Complex agreement}

In this agreement pattern, the participial form agrees in gender and number with $\mathrm{O}$ and the auxiliary agrees with $\mathrm{O}$ in person. It is attested in MSH, but only in the 3rd person. Braj (14), on the other hand, has preserved it in the 1st and 2nd pers.

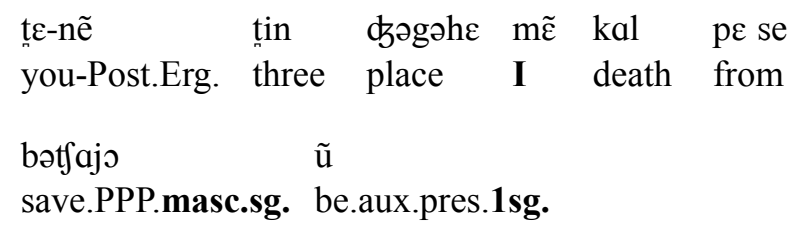

'You have saved me from death on three occasions.' (Braj) (Liperovskij 1988: 67, 147; 2007: 150)

\subsection{Agreement of pronominal $\mathrm{O}$ with the main verb}

Eastern Pahari - e.g. some subdialects of Kumauni and Garhwali - still allows the pronominal unmarked $\mathrm{O}$, which in turn triggers OV person-number agreement (Sharma 1987: 97; Juyal 1973: 143). Otherwise, O marking results in default agreement, following the MSH pattern (cf. example (3) with an unmarked pronominal $\mathrm{O}$ and (15) with $\mathrm{O}$ marked by the Dat./Acc. postposition and default agreement). Apart from personnumber OV agreement, which is a rare phenomenon, gender-number agreement of the unmarked pronominal $\mathrm{O}$ with the main verb is attested in Western Hindi (16). It has to be emphasized here that the maintenance of the unmarked pronominal $\mathrm{O}$ in the ergative domain has been perceived by scholars as proof of the greater resistance of the pronominal system to the process of nominativization (Khokhlova 2001: 163).

$$
\begin{aligned}
& \text { mətft } \int^{\text {h }} \text { r- } \varepsilon l \text { mI-ke buke de } \\
& \text { he-Post.Erg I. -Post.Dat./Acc. bite give.aux.PPP.sg. } \\
& \text { 'Mosquitoes bit me.' (Kumauni) }
\end{aligned}
$$


tations of the ne postposition in bardic poetry (Chand Bardai) cannot be taken seriously due to the disputed authenticity of the text. O marking was introduced very early in Western Hindi (16th c.), but it is a considerably later phenomenon in Eastern Pahari (cf. Wallace (1981) for an extensive discussion on Nepali) and in Western Pahari. ${ }^{4}$

Western Pahari continues to employ a synthetic instrumental ending inherited from MIA to mark A. Some Western Pahari and, to a lesser extent, Eastern Pahari dialects still preserve unmarked $\mathrm{O}$ where MSH has default marking (animate nouns, pronouns) (cf. Varma 1936: 147; Juyal 1973: 141; Ṭhākur 1975: 240).

5. The agentive postposition - its polyfunctionality

The ne marker, whose origin has been subject to a long-lasting debate that has never led to a generally accepted conclusion (see, for example, Montaut 2004a; 2004b: 65-66; 2006: 383; Stroński 2009, for detailed discussion on the origin of the marker), is considered to be the only monofuctional marker in MSH, but the dialects (Harauti, Ahirvati, Bangru and partly Braj) show its polyfunctionality (cf. Sigorskij 2000: 75).

The form of the agentive postposition used in Western Hindi is equal to the Dat./Acc. marker in Rajasthani. It has been postulated that the dative-ergative connection is thus palpable in the NIA dialects (cf. Butt 2005). In Harauti (cf. Allen 1960: 10; Śarmā 1991: 161) and Braj, the Dat./Acc. and Erg. usages are in complementary distribution (although the Harauti status its somehow labile - see (19) and (20)).

Due to increasing polyfuctionality of the ne postposition, Bangru (21) and Ahirvati (22) developed a "double oblique" system, which is usually considered to be unattested (cf. Comrie 1978: 330) in the languages of the world (although there are its traces in Pamir languages and Kashmiri; see Bubenik 1989: 182; Payne 1980; Skalmowski 1974).

$$
\begin{array}{llll}
\text { tf }{ }^{\text {h}} \text { oro } & \text { sãp } & \text { ne } & \text { marjo } \\
\text { boy } & \text { snake.masc. } & \text { Post.Dat./Acc. } & \text { hit.PPP.masc.sg. } \\
\text { 'A boy hit the snake.' (Harauti) (Śarmā } & \text { 1991: 161) }
\end{array}
$$

\footnotetext{
${ }^{4}$ According to Wallace (1982: 165), the introduction of the agentive postposition le in Nepali coincides with that of $n e$ in Western Hindi, but recent works of Poudel (2008) have predated this process to the end of 14th century. The language facts (mainly inscriptions) discussed by Poudel have to be further evaluated, but if they prove to be authentic, the probable introduction of analytic markers in NIA will have to be reanalyzed. Further complications arise when we analyze the inscriptional data from Kumauni - the earliest text dated 989 A.D. (Cauhān 2008: 1) shows regular usage of postpositions, while at the same time other NIA dialects had slowly begun a shift from synthetic to analytic type. This fact may itself put the authenticity of recently discovered texts in serious doubt.
} 
$\begin{array}{lllll}\mathrm{t} \int^{\mathrm{h}} \text { ora } & \mathrm{n} \varepsilon & \text { sãp } & \mathrm{i} & \text { marjo }\end{array}$ boy.Obl. Post.Dat. Snake.masc. emph. hit.PPP.masc.sg. 'A boy hit the snake.' (Harauti) (Śarmā 1991: 161)
babbu-ñ
t $\int^{\mathrm{h}}$ ore-n $\tilde{\varepsilon}$

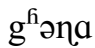
pitta

father-Post.Erg. son-Post.Acc./Dat. very much beat.PPP.masc.sg.

'The father beat the son very much.' (Bangru) (Khanḍelvāl 1980: 220)

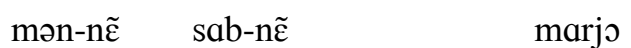

I-Post.Erg. master-Post.Acc./Dat. beat

'I beat the master.' (Ahirvati) (Yādav n.d.: 208)

Eastern Pahari, on the other hand, displays Instr./Erg. syncretism (23) of the postposition, which in turn can be considered a renewal of the previous synthetic pattern, still preserved in Western Pahari (24). The equal treatment of the ergative and of the other oblique cases (e.g. Instr.) fits with the extended Dixonian (Dixon 1979; 1994) scheme proposed by Klimov (1983: 113). The crucial difference between Dixon's and Klimov's models consists in the introduction of an Obl. argument, which in the ergative languages can be marked in the same manner as the main argument $\mathrm{A}$. The equal treatment of A and Obl. has been perceived as one of the implications of ergativity, and it has led scholars who have worked extensively on Caucasian languages to distinguish between "independent" and "combining" ergatives. The development of the former was conceived of as a sign of a later stage of ergativity, or in other words as a tendency towards nominativization (cf. Klimov 1973: 186-187; 1983: 112).

It is noteworthy that the Instr./Erg. syncretism is attested in Old Marwari texts (25), but it was lost at a very early stage (Khokhlova 2001: 161-162). ${ }^{5}$ Marwari thus displays very early attrition of the ergative pattern at the cost of the nominative one.

$$
\text { to wi-l jore-1 svote-1 maro }
$$

then he.Post.Erg. power.Post.Instr. stick-Post.Instr. beat.PPP.masc.sg.

'Then he beat (her) vehemently with a stick.' (Kumauni) (Pant 2006: 150)

\footnotetext{
${ }^{5}$ It would be at least tempting to ask why the pattern was lost in Marwari and preserved (or revived) in Pahari. A possible answer lies in the substratum - one of the hypotheses assumes an active typology of colloquial dialects which were in contrast with a "standard" IA language of nominative typology whose ergativization was a by-product of language contact with Tibeto-Burman tongues (Zakahryin 1979: 61-62; 68). It could have been a Dardic tongue or tongues with presumably strong active traits (Zakharyin 1982:42) or an unknown language " $X$ ", whose existence was once postulated while analyzing the unidentifiable layers of agricultural vocabulary in NIA (Masica 1979). A language of Khaśas ousted by the Rajput conquerors that had once come from the plains, as suggested by Grierson (Grierson 2005: 7-16), also cannot be excluded, although it has been recently rejected by Joshi on the basis of inscriptional data from Pahari (Joshi 1994; 2009).
} 
(24) maftar-ẽ $\quad$ Sohru hot $\mathrm{t}^{\mathrm{h}}$-ẽ zuku

teacher.Erg. boy hand.Instr. beat.PPP.masc.sg.

'The teacher beat a boy with his hand.' (Kului) (cf. Țhākur 1975: 240)

(25)

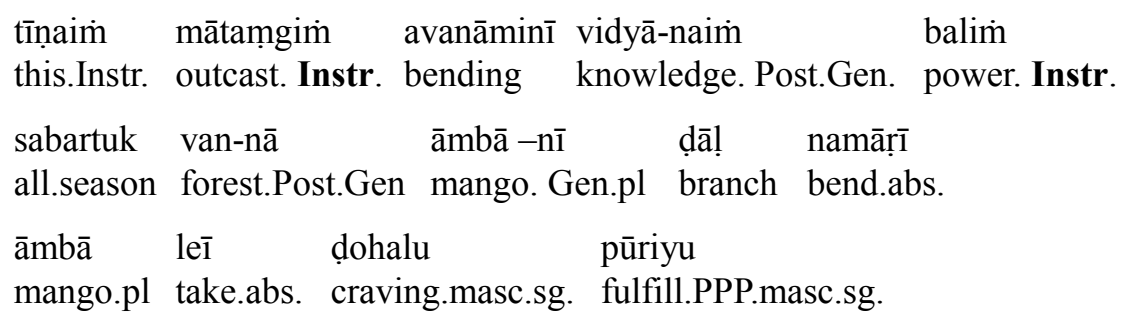

'This outcast with the power of knowledge of bending, having bent the branch of the all-season forest mangoes, fulfilled his craving.' (Marwari, 15th c. AD) (R.G. 15)

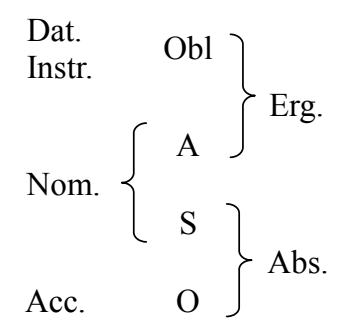

Figure 2. Nominative-accusative vs. ergative-absolutive alignment (Klimov 1983: 113).

For the obligative construction, Rajasthani still employs the Dat./Acc. postposition $n \varepsilon$ (26), preserving this structural convergence with Eastern Pahari, which uses for the same purpose the Erg. postposition $l(e)$ or $n e$ (27), while Western Pahari, being more conservative, displays the inherited synthetic Instr. marker instead of the postpositional one (28). This convergence cannot go unnoticed, since it indicates the former traits of ergative structures in Rajasthani and the existence of a strong ergative pattern in contemporary Pahari.

$$
\text { bin-ne roti } \quad \mathrm{k}^{\mathrm{h}} \mathrm{ani} \quad \mathrm{h} \varepsilon
$$
he.Post.Dat. bread.fem inf.fem. be.aux.3sg.

'He has to eat the bread.' (Shekhawati) (Gusain 2001: 39)

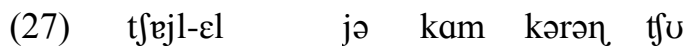
son.Post.Erg. this work do.inf. be.aux.3sg.

'The son has to do this work.' (Kumauni) 


\section{Degrees of ergativity in IA}

The ergativity metric proposed by Klaiman was based on a progressive scale, according to which the more ergative a language is, the more of the following properties it displays:

(a) The system has a tense-aspect conditioned split (a prerequisite for ergative main verb concord and auxiliary verb concord).

(b) In the ergative domain, the system has main verb concord with $\mathrm{O}$ for number (a prerequisite to having main verb concord with $\mathrm{O}$ for other parameters).

(c) Main verb concord can occur with marked $\mathrm{O}$ (a prerequisite for having auxiliary verb concord with marked $\mathrm{O}$ ).

(d) The system lacks identified object marking in the ergative domain (a prerequisite for lacking identified object marking in the nonergative domain and for having verbal concord with O for person) (Klaiman 1987: 96).

Consequently, Klaiman placed languages which do not block agreement with a marked $\mathrm{O}$ (e.g. Marwari) higher on the scale of ergativity than those in which the agreement blocking rule is operational (e.g. Bundeli). This is absolutely unacceptable in light of the dialectal data which have been presented above and which conform to the general tendencies observed, for example, for Rajasthani, Western Hindi and Pahari. ${ }^{6}$ There is no doubt that agreement with a marked $\mathrm{O}$ is a residue of ergativity, but the lack of $\mathrm{A}$ marking is a decisive factor to rank Marwari below dialects retaining A marking. Apart from that, dialects which preserve ergative alignment in the pronominal system should have the highest rank on the ergativity scale - as in the case of Western Pahari and partly Eastern Pahari. One must not forget that, although pronouns are more conservative as far as preservation of the agentive form is concerned, they are almost uniformly marked in the $\mathrm{O}$ function (which conforms to the Silverstein hierarchy). The process of ousting unmarked forms in the $\mathrm{O}$ function in the perfective tenses by marked ones is a well-attested phenomenon, and the occurrence of the unmarked pronominal $\mathrm{O}$ has to be taken into serious consideration when establishing any ergativity scale for NIA.

Another factor which should be decisive for the ergativity metric is the grouping together of A and Obl. Languages which are "strongly" ergative have no "independent"

\footnotetext{
${ }^{6}$ Even though Magier's (1983: 253) or Khokhlova's (2001) statements regarding attrition of ergativity in Rajasthani were not based on any precise metrics, they were intuitively correct and have been positively verified by first-hand dialectal data, which does not seem to be the case with Klaiman's model.
} 
ergative, and it is observable from our data that the dialects displaying Erg./Instr. syncretism are more ergative than those which have developed a separate ergative case.

There is no denying the fact that the development of the "tripartite" $(A \neq S \neq O)$ or "double oblique" $(A=O \neq S)$ system is a sign of the drift towards nominativity. Dialects in which such systems are operational are predominantly in a state of transition. Particularly the latter type is of an extremely labile character. Most of the dialects are resistant to the introduction of the double oblique system, and they tend to impose constraints on the use the syncretic markers (e.g. the Erg./Dat. postposition being in complementary distribution in Harauti).

Any splits in agreement actually weaken the ergativity pattern. They result in a split of the grammatical subject coding properties which are ascribed to $\mathrm{O}$ in the ergative construction. As a consequence, it leads to the coexistence of two distinct structures within one sentence - ergative and nominative - which is part of a more general tendency towards loss of ergativity.

Apart from the obvious flaws of Klaiman's proposal, particularly regarding the morphological marking of the main arguments, her model does not account for various degrees of ergativity at the level of syntax. This statement may appear too far-reaching in the context of morphologically ergative languages, but as I will try to demonstrate very briefly in the next section, it is not unjustified.

\section{No syntactic ergativity...}

IA languages are morphologically ergative, but at the level of syntax, they are exclusively nominative (cf. Pandharipande and Kachru 1977: 225-226). However, in the early NIA, there is evidence of a possible SO pivot ${ }^{7}-$ it has been attested e.g. in Old Marwari (Khokhlova 2001) and, presumably, it can be traced in other early NIA tongues as well. It is interesting that the pivot instability is still observable in Pahari (which, according to our metrics, constitutes the most ergative part of the "Hindi belt" continuum - cf. example (29)). If our intuitions are right, the NIA dialects spoken in the Himalayan region seem to be undergoing the syntactic change which happened in the dialects of the plains hundreds years ago.

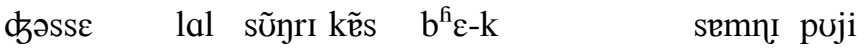

$$
\begin{aligned}
& \text { as soon as red pig little brother.Post.Gen. front reach.PPP.fem.sg. } \\
& \text { to wi-1 jore-1 svote-1 maro } \\
& \text { then s/he.Post.Erg. Power-Post.Instr. stick-Post.Instr. beat.PPP. masc.sg. }
\end{aligned}
$$

'As soon as the red pig (S) came in front of the little brother, he (i.e. the brother) beat (her) (O) vehemently.' (Kumauni) (Pant 2006: 150)

\footnotetext{
${ }^{7}$ I use the term "pivot" in the same meaning as Dixon (1994: 154).
} 


\section{Concluding remarks}

Undoubtedly, among all varieties spoken within the "Hindi belt", it is Pahari dialects that deserve the highest rank on the ergativity scale, with the Western branch on top, since these display ergative or tripartite alignment, still group $\mathrm{S}$ and $\mathrm{O}$ in the pronominal system, might display person agreement with $\mathrm{O}$, and show the same marking for $\mathrm{A}$ and Obl.

Western Hindi dialects occupy a somewhat intermediate position. Like the Pahari tongues, they also display ergative or tripartite alignment. In their pronominal system, $\mathrm{O}$ marking is prevalent and person agreement with $\mathrm{O}$ is unattested. They rarely group together A and Obl. and predominantly display agreement blocking.

Rajasthani varieties are the least ergative. They show exclusively accusative alignment. Pronominal $\mathrm{O}$ is always marked and no person agreement with $\mathrm{O}$ is attested. Rajasthani dialects never group together A and Obl. The only sign of the ergative pattern still existing in Rajasthani is OV agreement and the lack of agreement blocking with a marked $\mathrm{O}$.

In this very brief survey, I have tried to demonstrate that consideration of first-hand data even from a single dialectal group can (and indeed does) change our wellestablished views on the typology of ergative construction. What is more, even such a concise examination enables us to revise the hitherto proposed metrics, which are usually based on mass comparisons, often ignoring available language sources.

\section{LIST OF ABBREVIATIONS USED IN THE TEXT}

\author{
Abl. - ablative \\ Abs. - absolutive (case) \\ abs. - absolutive (conjunctive participle) \\ Acc. - accusative \\ aux. - auxiliary \\ compl. - completive \\ cont. - continuous \\ Dat. - dative \\ Dir. - direct case \\ Erg. - ergative \\ fem. - feminine \\ Gen. - genitive \\ imp. - imperative \\ inf. - infinitive
}

\author{
Instr. - instrumental \\ Loc. - locative \\ masc. - masculine \\ neut. - neuter \\ Nom. - nominative \\ M/NIA - Middle/New Indo-Aryan \\ MSH - Modern Standard Hindi \\ Obl. - oblique \\ pl. - plural \\ Post. - postposition \\ PPP - passive perfect participle \\ pres. - present \\ sg. - singular
}




\section{REFERENCES}

Allen, W.S. 1960. "Notes on Rājasthānī verb”. Indian Linguistics 21. 4-13.

Anderson, S.R. 1977. "On the mechanisms by which languages become ergative". In: Li, C. N. (ed.), Mechanisms of syntactic change. Austin: University of Texas Press. 217-264.

Bahl, K. 1972. On the present state of modern Rajasthani grammar. Jodhpur: Rajasthani Shodh Samsthan.

Bhānāvat, N. and L. Kamal (eds.). 1997-1998. Rājasthānī gadya: Vikās aur prakāś [Rajasthani prose: development and publicity]. Āgrā: Śrīrām Mehrā end Kampan̄̄. (R.G.)

Bubenik, V. 1989. “An interpretation of split ergativity in Indo-Iranian languages”. Diachronica 6(2). 181-212.

Butt, M. 1993. "Conscious choice and some light verbs in Urdu”. In: Verma, M.K. (ed.), Complex predicates in South Asian languages. New Delhi: Manohar Publishers and Distributors. 31-46.

Butt, M. 1995. The structure of complex predicates in Urdu. Stanford: CLSI Publications.

Butt, M. 2005. "The dative-ergative connection" $<$ http://ling.uni-konstanz.de/pages/home/butt/cssp05.pdf $>$

Butt, M. and T. Holloway King (eds.). 2006. Proceedings of the LFG 06 conference. Universität Konstanz: CSLI Publications. $<$ http://cslipublications.stanford.edu/LFG/11/lfg06.pdf>

Cauhān, C.S. 2008. Kumāuñ̄ bhāṣa ke abhilekh [The inscriptions of the Kumauni language]. Haldvānī: Ankit Prakāśan.

Comrie, B. 1978. "Ergativity". In: Lehmann, W.P. (ed.), Syntactic typology: Studies in the phenomenology of language. Texas: University of Texas Press. 323-393.

Das, P.K. 2006. Grammatical agreement in Hindi-Urdu and its varieties. München: Lincom Europa.

Dixon, R.M.W. 1979. "Ergativity”. Language 55. 59-138.

Dixon, R.M.W. 1994. Ergativity. Cambridge: Cambridge University Press.

Grierson, G.A. 2005 [1916]. Linguistic survey of India. (Vol. IX, Part VI.) Delhi: Low Price Publications.

Gusain, L. 2000. Bagri. München: Lincom Europa.

Gusain, L. 2001. Shekhavati. München: Lincom Europa.

Jha, S. 1985 [1958]. The formation of the Maithili language. New Delhi: Munshiram Manoharlal.

Joshi, M.P., 2009. "Advent of polities in Uttarkhand (Kumaon and Garhwal)". In: LecomteTilouine, M. (ed.), Bards and mediums: History, culture, and politics in the Central Himalayan kingdoms. Almora: Shri Almora Book Depot. 327-371.

Joshi, M.P. and V.S. Negi (eds.). 1994. "Was there a Central Pahari? An appraisal of Grierson's classification of three Pahari languages groups". In: Joshi, M.P., A.C. Fanger and C.W. Brown (eds.), Himalaya: past and present (Vol. III). Almora: Shree Almora Book Depot. 259-273.

Juyal, G. 1973. Madhya pahāṝ bhāṣā (gaṛvālī, kumāunī) kā anuśīlan aur uskā hind̄̄ se sambandh [The usage of Central Pahari language (Garhwali, Kumauni) and its connection with Hindi]. Lakhnau: Navayug Granthāgār.

Khaṇḍelvāl, Ś.K. 1980. Bã̃garū bolī kā bhāṣāśāstrīy adhyayan [A linguistic study of the Bangaru dialect]. Naī Dillī: Vāṇ̄i Prakāśan.

Khokhlova, L.V. 1992. "Trends in the development of ergativity in New Indo-Aryan". Osmania Papers in Linguistics 18. 71-89. 
Khokhlova, L.V. 2001. "Ergativity attrition in the history of Western New Indo-Aryan languages (Punjabi, Gujarati and Rajastahani)". The Yearbook of South Asian Languages and Linguistics. 159-184.

Khokhlova, L.V. 2006. "Sintaktičeskaja evolucija zapadnych novoindijskich jazykov v 15-20 vv."'Syntactic evolution of Western New-Indo-Aryan languages from 15-20 c.]. In: Dybo, A.V., V.A. Dybo, O.A. Mudrak and G.S. Starostin (eds.), Aspekty komparativistiki [Aspects of comparative studies]. Moskva: Rosijskij Gosudarstvennyj Gumanitarnyj Universitet (Orientalia et Classica: Trudy Instituta Vostočnych Kultur i Antičnosti, Vypusk VIII). 151186.

Klaiman, M.H. 1987. "Mechanisms of ergativity in South Asia". Lingua 71. 61-102.

Klimov, G.A. 1973. Očerk obščej teorii ergativnosti [An outline of the general theory of ergativity]. Moskva: Izdatel'stvo Nauka.

Klimov, G.A. 1983. Principy kontensivnoj tipologii [The principles of contensive typology]. Moskva: Izdatel'stvo Nauka.

Liperovskij, V.P. 1988. Očerk grammatiki sovremennogo bradža [An outline of the grammar of contemporary Braj]. Moskva: Izdatel'stvo Nauka.

Liperovskij, V.P. 1997. Očerk grammatiki sovremennogo avadhi [An outline of the grammar of contemporary Awadhi]. Moskva: Izdatel'stvo Nauka.

Magier, D. 1983. Topics in the grammar of Marwari. (Unpublished PhD disstertation, University of California, Berkeley.)

Manning, C.D. 1996. Ergativity. Argument structure and grammatical relations. Stanford: CSLI Publications.

Masica, C.P. 1979. “Aryan and non-Aryan elements in North Indian agriculture”. In: Deshpande, M.M. and P.E. Hook (eds.), Aryan and Non-Aryan in India. Ann Arbor: University of Michigan Center for South Asian and Southeast Asian Studies. 55-151.

Meščaninov, I.I. 1967. Ergativnaja konstrukcija v jazykach različnych tipov [The ergative construction in languages of different types]. Leningrad: Izdatel'stvo Nauka.

Montaut, A. 2004a. "Oblique main arguments in Hindi/Urdu as localizing predications". In: Bhaskararao, P. and K.V. Subbarao (eds.), Non-nominal Subjects. Amsterdam: John Benjamins. 33-56. Also available at $<$ http://anniemontaut.free.fr/publications.htm $>$.

Montaut, A. 2004b. A grammar of Hindi. München: Lincom Europa.

Montaut, A. 2006. "The evolution of the tense-aspect system in Hindi/Urdu, and the status of the ergative alignment”. In: Butt, M. and T. Holloway King (eds.), Proceedings of the LFG 06 conference. Universität Konstanz: CSLI Publications. 365-385.

Pandharipande R. and Y. Kachru. 1977. "Relational grammar, ergativity and Hindi-Urdu" Lingua 41. 217-238.

Pant, P. 2006. Kumāũñ̄ lok kathā [Kumauni folk stories]. Almora: Maniṣ Prakāśan.

Payne, J. R. 1980. "The decay of ergativity in Pamir languages". Lingua 51. 147-186.

Pirejko, L.A. 1968. Osnovnyje voprosy ergativnosti na materiale indoiranskich jazykov [Main questions pertaining to ergativity on the basis of lanaguage data from the Indo-Iranian languages]. Moskva: Izdatel'stvo Nauka.

Poudel, T. 2008. "Ergativity in Nepali: A historical perspective". Paper presented at the Workshop on Case and Alignment in Indo-European, University of Bergen, 10-11 December 2008.

Saksena, B. 1952. Dakkhinī hind̄̄ [Dakkhini Hindi]. Ilāhābād: Țaḍan Printing Works.

Saksena, B. 1971 [1937]. Evolution of Awadhi. Delhi: Motilal Banarsidass.

Šamatov, A.N. 1974. Klassičeskij dakxini [Classical Dakkhini]. Moskva: Izdatel'stvo Nauka.

Śarma, Ś. 1964. Dakkhinī hind̄̄ kā udbhav aur vikās [The origin and development of Dakkhini Hindi]. Prayāg: Hindī Sāhitya Sammelan. 
Śarmā, K. 1991. Pūrvī rājasthānī: Udbhav aur vikās [Eastern Rajasthani: Origin and development]. Jaypur: The Students Book Company.

Sharma, D.D. 1987. The formation of Kumauni language. Part II (Morphology and syntax). New Delhi: Bahri Publications.

Sigorskij, A.A. 2000. "Ergativnaja konstrukcja i kategoria vida v jazyke chindi" [The ergative construction and the category of aspect in the Hindi language]. Filologičeskije Nauki, Sbornik Naučnych Trudov 2(17). Moskva: Moskovskij Gosudarstvennyj Institut Meždunarodnych Odnošenij (Universitet).

Skalmowski, W. 1974. "Transitive verb constructions in the Pamir and Dardic languages". Studia Indoeuropejskie. Prace komisji Językoznawstawa 37. 205-212.

Stroński, K. 2009. "On the origin and function of the ergative postposition in Hindi and its varieties". Rocznik Orientalistyczny 62(1). 175-186.

Ṭhākur, M. 1975. Pahārī bhāṣā kuluī ke viśeș sãdarbh mẽ [The Pahari language with special reference to Kului]. Dillī: Sanmārg Prakāśan.

Trask, L.R. 1979. "On the origin of ergativity”. In: Plank, F. (ed.), Ergativity. Towards a theory of grammatical relations. London: Academic Press. 385-404.

Varma, S.1936. "The Rudhārī dialect". Indian Linguistics 6. 128-196.

Wallace, W.D. 1981. "Object-marking in the history of Nepali: A case of syntactic diffusion". Studies in the Linguistic Sciences 11(2). 107-128.

Wallace, W.D. 1982. "The evolution of ergative syntax in Nepali". Studies in the Linguistic Sciences 12(2). 147-211.

Yadāv, Ś. L. (n.d.). "Ahīrvāṭ̣̂”. In: Śārdā S. (ed.), n.d. Hariyāṇā kī upbhāṣāẽ [The dialects of Haryana]. Caṇụīgaṛh: Nideśak, Bhāṣā Vibhāg, Hariyāṇā. (27444 Govt. Press, Chandigarh.) 193-269.

Zakharyin, B. 1979. "On the formation of ergativity in Indo-Aryan and Dardic". Osmania Papers in Linguistics 5. 50-71.

Zakharyin, B. 1982. "Problemy jazykovych kontaktov w indijskich Gimalajach" [Problems of languge contacts in Indian Himalayas]. Vestnik Moskovskogo Universiteta 13(3). 31-42.

\author{
Address correspondence to: \\ Krzysztof Stroński \\ Institute of Linguistics \\ Adam Mickiewicz University \\ al. Niepodległości 4 \\ 61-874 Poznań \\ Poland \\ stroniu@amu.edu.pl
}

